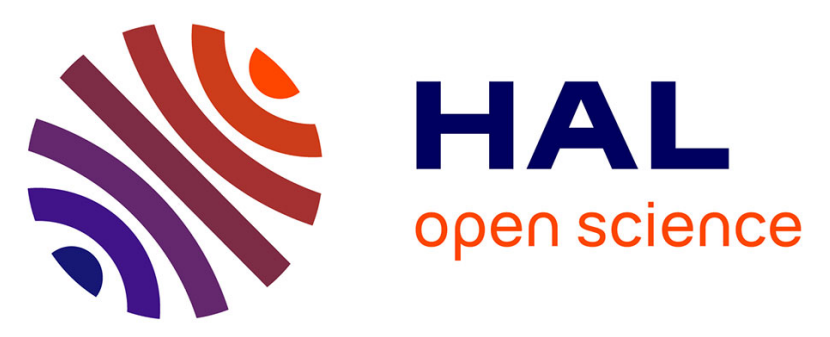

\title{
On the Use of Fluxgate 3-Axis Magnetometers in Archaeology: Application with a Multi-sensor Device on the Site of Qasr 'Allam in the Western Desert of Egypt
}

Bruno Gavazzi, Rozan Alkhatib-Alkontar, Marc Munschy, Frédéric Colin, Catherine Duvette

\section{To cite this version:}

Bruno Gavazzi, Rozan Alkhatib-Alkontar, Marc Munschy, Frédéric Colin, Catherine Duvette. On the Use of Fluxgate 3-Axis Magnetometers in Archaeology: Application with a Multi-sensor Device on the Site of Qasr 'Allam in the Western Desert of Egypt. Archaeological Prospection, 2017, 24 (1), pp.59 - 73. 10.1002/arp.1553 . hal-01624846

\section{HAL Id: hal-01624846 \\ https://hal.science/hal-01624846}

Submitted on 1 Feb 2021

HAL is a multi-disciplinary open access archive for the deposit and dissemination of scientific research documents, whether they are published or not. The documents may come from teaching and research institutions in France or abroad, or from public or private research centers.
L'archive ouverte pluridisciplinaire HAL, est destinée au dépôt et à la diffusion de documents scientifiques de niveau recherche, publiés ou non, émanant des établissements d'enseignement et de recherche français ou étrangers, des laboratoires publics ou privés. 


\section{Archaeological Prospection}

\section{On the use of fluxgate 3 -axis magnetometers in archaeology: application with a multi-sensor device on the site of Qasr 'Allam in the Western Desert of Egypt.}

\begin{tabular}{|r|l|}
\hline Journal: & Archaeological Prospection \\
\hline Manuscript ID & ARP-16-0005.R1 \\
\hline Wiley - Manuscript type: & Research Article \\
\hline Date Submitted by the Author: & n/a \\
\hline Complete List of Authors: & $\begin{array}{l}\text { Gavazzi, Bruno; Université de Strasbourg, Institut de Physique du Globe de } \\
\text { Strasbourg; Université de Strasbourg, Archéologie et histoire ancienne : } \\
\text { Méditerranée - Europe } \\
\text { Alkhatib-Alkontar, Rozan; Université de Strasbourg, Institut de Physique du } \\
\text { Globe de Strasbourg } \\
\text { Munschy, Marc; Université de Strasbourg, Institut de Physique du Globe de } \\
\text { Strasbourg } \\
\text { Colin, Frédéric; Université de Strasbourg, Archéologie et histoire ancienne : } \\
\text { Méditerranée - Europe; Institut Français d'Archéologie Orientale } \\
\text { Duvette, Catherine; Université de Strasbourg, Archéologie et histoire } \\
\text { ancienne : Méditerranée - Europe }\end{array}$ \\
\hline Keywords: & $\begin{array}{l}\text { Multi-sensors, Magnetic compensation, Magnetometry, 3-axis fluxgate } \\
\text { magnetometers, Potential field transformations, Vertical vector fluxgate }\end{array}$ \\
\hline
\end{tabular}


1 On the use of fluxgate 3-axis magnetometers in archaeology: application with a

\section{multi-sensor device on the site of Qasr 'Allam in the Western Desert of Egypt.} Bruno Gavazzi (corresponding author) ${ }^{\text {a, b }}$ (bgavazzi@unistra.fr ; Phone +33368850473 ; mobile +33607639713), Rozan Alkhatib-Alkontar ${ }^{\mathrm{a}}$, Marc Munschy ${ }^{\mathrm{a}}$, Frédéric Colin ${ }^{\mathrm{b}, \mathrm{c}}$, Catherine Duvette

${ }^{a}$ UMR 7516, Institut de Physique du Globe de Strasbourg (IPGS), École et Observatoire des Sciences de la Terre (EOST), University of Strasbourg, Bâtiment Blessig, 1 rue Blessig, F-67084 Strasbourg cedex, France.

${ }^{\mathrm{b}}$ UMR 7044, Archéologie et histoire ancienne : Méditerranée - Europe (Archimède), Maison Interuniversitaire des Sciences de l'Homme - Alsace (MISHA), University of Strasbourg, 5 allée du Général Rouvillois, F-67083 Strasbourg cedex, France.

'Institut Français d'Archéologie Orientale (IFAO), 37 rue al-Cheikh Ali Youssef, B.P. 11562 Qasr al-Aïny 11441 Cairo, Egypt.

Running head: Fluxgate 3-axis magnetometers in archaeology: a multi-sensor device

Sponsor: The study was sponsored by the Initiatives d'Excellence (IdEx, Programme Investissements d'Avenir) of the University of Strasbourg.

\section{Abstract}

Fluxgate 3-axis magnetometers are seldom used on archaeological sites due to their lack of precision. Nonetheless, they offer light weight, low power consumption and the ability of compensation of the magnetization of the prospecting device. This study proposes to use calibration and compensation processes developed for space research and aerial measurement to build a multi-sensors and georeferenced device to assess deep and shallow objects for large scale archaeological investigations in Qasr 'Allam, in a context of heavy sedimentary coverage and uneven surface. The use of the device on the site in combination with potential field transformations of the signal such as the double reduction to the pole and the vertical derivative reveal a vast irrigation system as well as a large cultic facility. A comparison with gradiometric measurements shows a resolution at least as good for shallow sources. The precise positioning allows to perform targeted excavations which validate the geophysical interpretations and offer new archaeological information. These discoveries give enough proof to the local authorities to clearly delimit the area to be protected from the threatening progression of agricultural fields.

Keywords: Magnetometry, 3-axis fluxgate magnetometers, Multi-sensors, Magnetic compensation, Potential field transformations, Vertical vector fluxgate. 


\section{Introduction}

37 Situated in the Western Desert of Egypt, the oasis of Bahariya (Figure 1) is inhabited 38 since Prehistory (Svoboda, 2006; 2013). The main phases of the ancient Egyptian 39 civilization can be observed in the area. However, they are not as well documented as in 40 the Nile valley because only a few scholars have studied the Bahariya region. This is 41 mainly due to access difficulties until construction of road infrastructure in the mid- $20^{\text {th }}$ 42 century. The growing number of investigations took place since the end of the nineties. 43 They revealed the archaeological potential of the area for illustration of a locally badly 44 known period, ranging from the Third Intermediate Period to the Roman times, (i.e. 45 from the $9^{\text {th }}$ century B.C. to the $3^{\text {rd }}$ century A.D. (Colin, 2013a, pp. 151-152)). This 46 paper focuses on the site of Qasr 'Allam (Figure 1), which integrity is threatened by 47 heavy sedimentary processes and the rapid site destruction by recent increases in 48 agricultural development. Geophysics is used to locate and study the archaeological 49 remains of a historically significant dwelling.

\section{The site of Qasr ‘Allam}

51 Before any archaeological study, the site of Qasr 'Allam was known mostly as a 52 rectangular structure emerging from the sand which was interpreted by the inhabitant as 53 an Arabic fort (Colin and Labrique, 2003, pp. 169-170). More than ten years of 54 excavation then revealed facilities buried within sand and mud to be composed of 55 mudbrick buildings of different natures, such as housings, storerooms and workshops 56 (Figure 2, A-B-C). These structures were interpreted as part of a wide religious estate, the "Domain of Amun" according to stamped potteries found in the domestic 58 dump sites of the dwellings. Two periods of occupation can be identified from $9^{\text {th }}$ to $7^{\text {th }}$ 59 centuries B.C. (Colin, 2011, pp. 57-68). A complex network of fossilized irrigation

60 structures can be identified through the traces of wells as well as open and underground 61 channels surrounding the dwelling. In nowadays arid landscape most of these structures 62 are partially or totally covered with sand. Often, only the materials excavated during construction and maintenance are visible on the surface (Figure 2, A-D-E-F).

64 These discoveries might indicate that the site could be a well preserved example of a 65 complete cultic facility with three main components: a cultic core, associated domestic 
66 buildings and its surrounding agricultural domain, of which most parts are still buried 67 within the ground. The structural organization of the excavated buildings suggests 68 indeed that they were only an annex in the periphery of a much larger and central 69 religious facility (Colin, 2011, pp. 65-66; Colin and Duvette, 2012, pp. 161-162). 70 According to this hypothesis, the direction of the access ramp of a cellular foundation 71 platform (Figure 2, A-B), whose typology is well known in the Nile valley (Spencer, 72 1979a, pp. 116-118; Spencer, 1979b; Traunecker, 1987; Leclère, 2008, pp. 630-636; 73 Malecka-Drozd, 2014), would indicate that the presumed core is located westwards, 74 where lies a sand dune a few metres thick and where no archaeological traces are visible 75 on the surface.

However, this hypothesis suffers from two uncertainties: 1- the lack of traces on the surface of the complex core; 2 - the lack of information on the spatial and chronological links between the buildings and the irrigation system.

Answers to these problems could be gained from a geophysical imaging of the subsurface. The surveying strategy should then take into account strong constraints: the area is highly threatened from the west by the agricultural development, increasing every year. Therewith, the whole dune shows an uneven topography scattered with dried 83 halfa grass and bushes reaching a height up to $0.8 \mathrm{~m}$. Thus, the prospection of the area must be fast and adapted to the roughness of the terrain.

\section{Choice of the geophysical method}

In such a context, the most appropriate solution would appear to be the magnetic methods. Geomagnetism is a popular and effective method for archaeological purposes (Linford, 2006; Gaffney, 2008). The main advantages are: -1- the anthropic traces show usually a strong contrast of magnetization with their surroundings; -2- the rapidity of measurement and light weight of the sensors to allow mapping of large surfaces with a

91 high density of data. In addition, a first prospection using vector gradiometer (Geoscan 92 FM256) was conducted between the sand dune and the platform in 2006 and 2010 by 93 Tomasz Herbich (Herbich, 2011). It revealed irrigation structures as well as walls and 94 foundation trenches (Colin, 2006; Colin, 2010; Herbich, 2011), thus giving evidence of 95 a contrast of magnetization strong enough to identify the archaeological remains. 96 However, the study of Herbich (2011) also revealed some limitations over the sand 97 dune: the topography and vegetation make the implementation of a grid and the 
98 measurements less than $0.8 \mathrm{~m}$ above the ground highly difficult without an intense

99 preparation of the field. Moreover, one of the properties of the vertical gradient is to 100 enhance short wavelength and to smooth out large wavelength variations of the 101 magnetic field. This makes gradiometers extremely sensitive to shallow objects but of 102 limited capability to identify deeper sources or lower magnetic contrasts as it is the case 103 for Qasr 'Allam (Blakely, 1995, pp. 324-326; Fagaly, 2001, pp. 327-328). This paper 104 proposes to overcome these limitations by adapting the measurement of the total 105 magnetic field with 3-axis vector fluxgate magnetometers, usually used in space 106 research or mining exploration (Nabighian et al., 2005), and more recently for the 107 detection of unexploded ordnances (Munschy et al., 2007), to archaeological surveys.

108 Method

109 Device

110 The core of the developed method lies in the measurement of the intensity of the 111 magnetic field with fluxgate magnetometers. Such magnetometers (Figure 3, A) have 112 the advantage of being light $(80 \mathrm{~g})$ and consuming low energy $(<1 \mathrm{~W})$. Their three 113 orthogonal sensors allow the measurement of the three components of the magnetic 114 field at rate up to more than $1000 \mathrm{~Hz}$ (Primdahl, 1979), from which the total field can 115 easily be calculated. The device developed for this study (Figure 3, C) is built around an 116 in-house developed electronics (Figure 3, B). It powers the rest of the instrument, 117 digitizes and stores the data of 1 to 8 magnetometers as well as 1 to 2 global navigation 118 satellite system (GNSS) antennas. The electronics is mounted on a backpack and 4 119 magnetometers are placed $0.5 \mathrm{~m}$ apart from each other in front of the operator, one 120 metre above the ground. A GNSS antenna is placed at the top of the backpack for the 121 navigation. Both navigation and magnetic data are displayed in real time through a head 122 mounted display (HMD). The device weighs less than $15 \mathrm{~kg}$ and can be operated by a 123 single person who follows parallel survey lines set every $2 \mathrm{~m}$ and displayed in the 124 HMD. Thus, georeferenced magnetic profiles are acquired every $0.5 \mathrm{~m}$ centred on each 125 survey line without any preparation on the field. In Qasr 'Allam, $5000 \mathrm{~m}^{2}$ to $12000 \mathrm{~m}^{2}$ 126 of magnetic data were acquired per hour of measurement.

$127 \quad$ Calibration and compensation 
128 The major disadvantage of the fluxgate magnetometers is of being relative devices.

129 This means that the instrument requires a precise calibration before each session of 130 measurements to correct errors of sensitivity, offset and angle. This problem is well 131 known and various techniques of calibration have been developed. In this study the 132 calibration is done using a process developed initially for space research (Olsen et al., 133 2003). It consists in the rotation of the magnetometers (or the whole device) in all 134 direction around a fixed point where the magnetic field can be considered steady. The 135 registered variations of the magnetic field are therefore only due to the different kinds of 136 errors which can then be minimized using a least squares method. The advantage of the 137 process is that it also compensates the remnant and induced magnetization of the device 138 itself (Munschy et al., 2007). This makes the fluxgate the only magnetometer capable of 139 such compensation, allowing compact multi-sensor devices as well as motorized 140 measurements. A typical result of the effect of the calibration and compensation process 141 on a magnetometer is shown in Figure 4, where computed parameters reduce the 142 variations of measurements at a fixed point from around $200 \mathrm{nT}$ to $0.3 \mathrm{nT}$.

\section{$143 \quad$ Time-dependant variations}

144 Another issue with the measurement of the total magnetic field is the correction of 145 the time-dependant variations which may be caused by extra-terrestrial sources or 146 anthropic activities. Additionally, fluxgate magnetometers are not absolute and subject 147 to drift with the change of temperature $\left(0.1\right.$ to $0.5 \mathrm{nT} /{ }^{\circ} \mathrm{C}$ according to the manufacturer). 148 In an environment affected by homogeneous but not linear temporal variations, as it is 149 often the case in urban areas, corrections can be made by using a magnetometer 150 installed at a fixed point (base station) during the measurements, thus recording only the 151 time dependant part of the signal. Such solution was not possible in Qasr 'Allam due to 152 legal and logistical difficulties to have a base station on the site at the time of the study. 153 However, during the surveying hours (6 to 10 a.m.), time-dependant variations are 154 linear and can therefore be easily corrected. They are the result of a combination of 155 effects from a temperature drift as well as from far external sources of which the linear 156 variation is confirmed by using geomagnetic records of one of the nearest 157 INTERMAGNET observatory (Tamanrasset).

$158 \quad$ Data processing 
159 The measurement provides the 3 calibrated components of the total magnetic field, 160 from which the total magnetic intensity is calculated. In archaeology the prime interest 161 is to measure/illustrate subtle spatial variations of the magnetic field. This is achieved 162 by observing the anomalies of the total magnetic field's intensity. The anomaly is 163 defined as the difference between the intensity of the measured magnetic field and the 164 regional field (Blakely, 1995, pp. 178-180). The latest is computed using the 165 International Geomagnetic Reference Field (IGRF) (Finlay et al., 2010). The anomaly 166 of the intensity of the total magnetic field can then be displayed either as profiles or as 167 maps after a gridding computerized operation (D'Errico, 2005). The node distance of 168 the grid is usually set as half of the distance between each magnetometer, i.e. $0.25 \mathrm{~m}$ in 169 this study. After this procedure, the residual errors can lead to the appearance of a 170 levelling effect between profiles (Fedi and Florio, 2003). To solve this problem, the 171 differences at the crossing points between the values on magnetic profiles (in-lines) and 172 traverses (tie-lines) are measured. Then, a constant to apply to each profile is calculated 173 by a linear inversion to minimize the differences at the crossing points.

\section{Results}

175 The data acquisition over the Qasr 'Allam site took place in April and May 2012. 176 Through $200 \mathrm{~km}$ of survey lines, more than $800 \mathrm{~km}$ of georeferenced magnetic profiles 177 were recorded over an area about $340,000 \mathrm{~m}^{2}$ (Figure 5).

\section{$178 \quad$ Maps of magnetic anomalies}

179 Usually, magnetic anomalies are represented using maps with a linear colour scale. 180 Those consist in attributing a colour or grey tone to each node of the grid according to 181 its value using a linear scale, as shown in Figure 6. Unfortunately, such a representation 182 is often not sufficient to show accurately all the anomalies of a site, as they can range 183 from a few to hundreds of nano-Tesla. A common solution to this problem is to display 184 multiple maps with different scales to understand the anomalies from the largest to the 185 smallest. Such a process might be time consuming and is not the most practical, as 186 several maps have to be observed at the same time. To overcome this problem, we 187 introduce another approach, the equi-populated mapping. An equi-populated map 188 consists in attributing a shade (or colour) to each node using a non-linear scale in such a 
way that all the shades are evenly distributed on the map. Thus, both small and strong magnetic anomalies can be represented on a unique map, as shown in Figure 7.

From both representations (Figure 6-7), different kind of anomalies can be observed on the site. Depending on their wavelength and shape, they can be ranked as follows.

- Dipolar anomalies: the strongest one in the west is due to a metallic pole; the others are due to pieces of metal which are scattered everywhere on the site, showing no particular distribution.

- Short wavelength lineation (about $1 \mathrm{~m}$ and less): they are the most common anomalies and can be sorted in different subgroups. In the southern part, a high concentration of curved lines following roughly N-S and E-W orientations is present. A similar pattern can be seen in the northern part, though in much smaller quantities. In the central part, the lines are straighter and follow an orientation similar to the one of the large wavelength lineation surrounding them.

- Large wavelength lineation (about $10 \mathrm{~m}$ ): they approximatively draw two rectangles of $150 \times 100$ and $125 \times 100 \mathrm{~m}$ in the central part of the map. Their orientation is of a few degrees east.

- North-south gradient: the magnetic anomaly field decreases of about $20 \mathrm{nT}$ from north to south. This gradient cannot be explained by the regional magnetic field as the International Geomagnetic Reference Field gives an increase of 3.8 nT from north to south. Thus, it is likely that such a gradient is due to a deep local variation of the underlying geology.

These anomalies reveal the presence of different kind of magnetic heterogeneities within the ground. Unfortunately, the shape, amplitude and position of an anomaly (as well as the gradient) depend on multiple factor such as the shape, the orientation, the position and magnetization of the source as well as the orientation of the regional magnetic field. To decipher these anomalies, interpretation tools can be found in potential field theory.

\section{Potential field transformations}

In any kind of magnetometry, the horizontal position of the sources is situated somewhere in between the positive and negative extrema of a skewed anomaly. When 
220 the wavelength is shorter than the size of the object, as it is often the case for very 221 shallow objects, this is not a problem. Otherwise, as it is often the case in this study, the 222 error can reach up to a few metres, which is not acceptable to locate properly 223 archaeological trenches. Fortunately, the position of the remains can be obtained by 224 using a potential field transformation known as the double reduction to the pole (DRP). 225 The DRP consists in the calculation of the signal when both the magnetization and 226 regional field are set vertical. Thus the anomalies become symmetrical with their 227 maxima above their sources (Baranov, 1957). In the spectral domain, the operation is 228 easily done by multiplying the spectrum of the anomaly by

$$
\left[\frac{i \sqrt{u^{2}+v^{2}}}{a u+b v+i c \sqrt{u^{2}+v^{2}}}\right]\left[\frac{i \sqrt{u^{2}+v^{2}}}{a^{\prime} u+b^{\prime} v+i c^{\prime} \sqrt{u^{2}+v^{2}}}\right]
$$

229 where $u$ and $v$ are the wavelengths associated with $x$ and $y$ directions, $i^{2}=-1$, $230(a, b, c)$ the components of the unit vector in the direction of the regional magnetic 231 field, and $\left(a^{\prime}, b^{\prime}, c^{\prime}\right)$ the components of the unit vector in the direction of the 232 magnetization (Bhattacharyya, 1965). The direction of the regional field is given by the 233 IGRF while the direction of magnetization is either set as the same as the regional field 234 when the ratio remnant/induced magnetization is near zero or obtained through 235 successive iterations until the signal become symmetrical. In Qasr 'Allam, as the 236 buildings are made in mudbricks, the orientation of magnetization was set equal to that 237 of the regional field. In Figure 8, the anomalies become symmetrical, confirming this 238 induced-only magnetization hypothesis. It must be noted that a simple reduction to the 239 pole (only one vector set vertical) does not give the position of the source (Figure 8). 240 The calculated DRP map gives therefore the position of sources visible or not on the 241 surface (Figure 9). The archaeological interpretation stays difficult due to the presence 242 of a very large wavelength anomaly most probably due to the geology. An easy way to 243 enhance the shortest wavelength while smoothing the largest ones is the use of the 244 vertical derivative. The operation is straightforward in the spectral domain and 245 corresponds to the multiplication of the spectrum of the map by

$$
\left(\sqrt{u^{2}+v^{2}}\right)^{n}
$$


246 where $u$ and $v$ are the wavelengths associated with $x$ and $y$ directions and $n$ is the order 247 of derivation. Figure 10 corresponds to the map obtained after computing the vertical 248 gradient of the DRP. It can be observed that the different lines are indeed enhanced and, 249 most importantly, new lineations appear, especially in the central area.

Comparison with gradiometry

251 To assess the quality of the data for archaeological interpretation compared to 252 gradiometry, the area surveyed by Herbich (2011) with a fluxgate gradiometer (Geoscan 253 FM256) was also covered with the device developed in this study. The comparison of 254 the results (Figure 11) shows that the proposed method reveals at least as many 255 information as a vector gradiometer, even though the magnetometers are more distant 256 from the ground $(1 \mathrm{~m})$. The vertical derivative map (Figure 11, A) appears more blurred 257 than the gradiometric map (Figure 11, B) because it corresponds to a more distant 258 acquisition from the sources.

\section{Discussion}

$260 \quad$ Interpretation of magnetic anomalies

261 The different maps give important information on the sources of the magnetic 262 anomalies. The different linear anomalies can be interpreted as highly probable 263 archaeological remains and are divided into three categories: long wavelengths, straight 264 and non-straight short wavelengths. The non-straight linear elements with short 265 wavelengths follow the same rough orientation pattern and shape as the irrigation 266 structures visible on the ground surface. Some of them directly follow the traces of the 267 irrigation structures observed on the ground surface. They are also mostly connected to 268 an area of visible wells in the south eastern part of the site (Figures 2 and 5). This 269 strongly suggests that those anomalies can be interpreted as irrigation structures, present 270 not only under the sand dune, but also within the harder ground in the whole area 271 (Figure 12). A targeted excavation of such a structure within the sand dune (Figure 12, 272 area 15) confirmed open irrigation channels under $1.2 \mathrm{~m}$ of sediments (Colin and 273 Duvette 2012, pp. 163-164). The filling sediments of one segment contained artefacts 274 (potteries, terracotta figurines) of a well-attested type, according to the local typology of 275 the $8^{\text {th }}$ or the $7^{\text {th }}$ century B.C. (Colin and Duvette, 2012, p. 164). This information 276 validates the hypothesis that at least one part of the irrigation network was 
277 contemporary to the cultic complex and that these farming devices most probably 278 belonged to the religious estate.

279 The two other types of linear anomalies can be interpreted differently. They are 280 situated in front of the access ramp of the platform, where the rest of a religious facility 281 can be expected. They show angular shapes, and display an orientation similar to the 282 one of the already excavated constructions. It can therefore be stated that they most 283 likely correspond to ancient buildings, thus enlarging the surface of the whole facility 284 from $40000 \mathrm{~m}^{2}$ to $150000 \mathrm{~m}^{2}$ (Figure 12). The variability of wavelengths can be 285 explained as different depths of sources, either due to the variability of the post286 abandonment sedimentary deposits, to different sizes of structures or to successive 287 archaeological periods. This is verified by two targeted excavations which started in 2882013 and 2014 and are still in progress (Figure 12, areas 16 and 17). They revealed the 289 presence of cultic buildings corresponding to the magnetic anomalies at different depths 290 from 0.15 to 2.4 metres (Figure 12, area 16 and 17 respectively) which are related to 291 different occupations from at least the $8^{\text {th }}$ or the $7^{\text {th }}$ century B.C. to the $2^{\text {nd }}$ century A.D. 292 and are affected by an environmental change (Colin, 2013b; Colin et al., 2014). The 293 stratigraphy of the tested areas revealed that the sedimentary processes followed two 294 successive patterns. The ruins of the last occupation period (Roman times) are mainly 295 covered by aeolian sand in an arid context, but the remains of the former periods (from 296 Third Intermediate Period until Late Period or later) are filled with alluvial earthen 297 sediments, in a seemingly more humid context.

\section{The 3-axis fluxgate magnetometer total field approach}

In addition to the interpretation results, the study reveals the potential of the use of 3axis fluxgate magnetometers for large scale archaeological surveys. The light weight of the magnetometers and their compensation ability allow the construction of a compact multi-sensors device which can be operated by a single technician. At least four simultaneous georeferenced magnetic data without any preliminary preparation of the 304 site can be acquired. The position of the magnetometers $1 \mathrm{~m}$ above the ground surface 305 allow to cover areas with more vegetation or a more uneven topography than with a 306 gradiometer device. Using vertical gradiometry, the lower probe is usually situated 0.2$3070.3 \mathrm{~m}$ above the ground surface. Thus, the proposed approach proved to be capable to 308 survey 5000 to $12000 \mathrm{~m}^{2}$ per hour with a $0.5 \mathrm{~m}$ spacing and reveal at least as many 
309 information on archaeological remains as a gradiometer through the use of the vertical 310 derivative of the signal (Figure 11). The application of the DRP gives theoretically the 311 exact horizontal position of the sources, unlike a single reduction which leads to a 312 residual skewness. If the difference or even the use of a reduction can be negligible for 313 very shallow sources, it is not the case with deeper sources, as shown in Figure 8 and 314 the comparison between Figure 7 and 9.

\section{Conclusion}

316 The study both validates the application of an innovative approach to magnetic 317 prospections in archaeology and reveals important information on the site of Qasr 318 'Allam.

319 The use 3-axis fluxgate magnetometers and associated potential field 320 transformations proved to be efficient to reveal information on both deep and shallow 321 archaeological sources at a large and rapid scale. The results obtained in Qasr 'Allam 322 offer two prospects for further development: 1- doubling the speed of acquisition by 323 doubling the number of magnetometers; 2- using the compensation ability to develop a 324 smaller device which allows a few centimetres spacing between sensors for high 325 precision small scale surveys.

In Qasr 'Allam, the geophysical survey strengthens the hypothesis of the archaeologists. It locates remains of large scale buildings positioned in the expected area, whose general plan and direction are consistent with the hypothesis of a religious complex which combines a main cultic centre (totally covered by sediments) with economic and domestic facilities (of which parts were previously excavated). The accurate positioning of probable archaeological structures has allowed setting up targeted excavations that led to important results: parts of the irrigation network were already used from the $8^{\text {th }}$ or $7^{\text {th }}$ century B.C. in the vicinity of the buildings, the site was used for cultic purposes to at least the $2^{\text {nd }}$ century B.C. and was impacted by a rapid environmental change from humid to arid in the latest periods of occupation. Without the results provided by the magnetic mapping, the thickness of the sedimentary deposits would have discouraged any attempt to explore the underground by means of the 338 classical archaeological digging methods. A next step would be to investigate further 339 the supposed cultic centre and the associated environmental change to find further 340 chronological and functional data. According to its size and the thickness of sediment, 
341 the study would need the combination of archaeological excavations and a more

342 detailed geophysical method. In consequence, these conclusions encouraged the

343 Egyptian Supreme Council of Antiquities (SCA) to delimit an area to be protected in

3442014 to avoid the destruction of remains by the fast progression of agricultural fields.

\section{$345 \quad$ Acknowledgement}

346 Some of the results presented in this paper rely on the data collected at Tamanrasset

347 observatory. We thank Centre de Recherche en Astronomie, Astrophysique et 348 Geophysique as well as Institut de Pysique du Globe de Paris, for supporting its 349 operation and INTERMAGNET for promoting high standards of magnetic observatory 350 practice (www.intermagnet.org). The authors would like to thank the Initiatives 351 d'Excellence (IdEx, Programme Investissements d'Avenir) of the University of 352 Strasbourg for their financial support as well as Laurent Ameglio, Daniel Sauter, 353 Nicolas Florsch, Chris Gaffney and the two anonymous reviewers for their advices and 354 constructive comments.

\section{$355 \quad$ References}

356 Baranov V. 1957. A new method for interpretation of aeromagnetic maps: pseudo357 gravimetric anomalies. Geophysics 22: 359-383. DOI: 10.1190/1.1438369

358 Bhattacharyya BK. 1965. Two-dimensional harmonic analysis as a tool for magnetic 359 interpretation. Geophysics 30: 829-857. DOI: 10.1190/1.1439658

360 Blakely RJ. 1995. Potential Theory in Gravity and Magnetic Applications. Cambridge 361 University Press. ISBN: 0-521-41508-X

362 Colin F. 2006. Bahariya. In: Pantalacci L, Denoix S (Eds.). Travaux de l'Institut 363 Français d'Archéologie Orientale en 2005-2006. Bulletin de l'Institut Français 364 d'Archéologie Orientale 106: 404-409.

365 Colin F. 2010. Bahariya. In: Midant-Reynes B, Denoix S (Eds.). Travaux de l'Institut 366 Français d'Archéologie Orientale en 2009-2010. Bulletin de l'Institut Français 367 d'Archéologie Orientale 110: 326-331.

368 Colin F. 2011. Le «Domaine d'Amon» à Bahariya de la XVIII à la XXVI ${ }^{\mathrm{e}}$ dynastie : 369 l'apport des fouilles de Qasr 'Allam. in: Devauchelle D. (Ed.), La XXVI Dynastie 370 Continuités et Ruptures. Actes Du Colloque International Organisé Les 26 et 27 371 Novembre 2004 à l'Université Charles-de-Gaulle-Lille 3. Promenade Saïte Avec Jean 372 Yoyotte: 47 - 84. Paris. 
373 Colin F. 2013a. Les gisements archéologiques de Psôbthis au début du XXI ${ }^{\mathrm{e}}$ siècle : 374 Diagnostic sur un paysage menacé et nouvelles orientations de recherche. in: Dospěl, 375 M., Suková, L (Eds.). Bahriya Oasis: Recent Research into the Past of an Egyptian 376 Oasis: 151-184. Charles University; Prague.

377 Colin F. 2013b. Bahariya. Pratiques funéraires et lieux de culte. In: Midant-Reynes B 378 (Ed.). Rapport d'activité 2012-2013, Supplément au Bulletin de l'Institut Français 379 d'Archéologie Orientale 113: 246-251.

380 Colin F, Duvette C. 2012. Bahariya. Pratiques funéraires et lieux de culte. In: Midant381 Reynes B (Ed.). Rapport d'activité 2011-2012, Supplément au Bulletin de l'Institut 382 Français d'Archéologie Orientale 112: 159-165.

383 Colin F, Duvette C, Gavazzi B, Munschy M, Schuster M, Schwarz D. 2014. Bahariya. 384 Pratiques funéraires et lieux de culte. In: Midant-Reynes B (Ed.). Rapport d'activité 385 2013-2014, Supplément au Bulletin de l'Institut Français d'Archéologie Orientale 114: 386 195-201.

387 Colin F, Labrique F. 2003. Recherches de terrain en Égypte. Chronique. Dialogues 388 d'histoire ancienne 29 (2): 165-185. DOI: 10.3406/dha.2003.1569

389 D’Errico J. 2005. Surface Fitting using gridfit.

390 (http://www.mathworks.com/matlabcentral/fileexchange/loadFile.do?objectId=8998),

391 MATLAB Central File Exchange.

392 Fagaly R L. 2001. Supercoducting Quantum Interference Devices (SQUIDs). In: Ripka 393 P (Ed). Magnetic Sensors and Magnetometers: 305-347. Artech House. ISBN: 1-58053$394 \quad 057-5$

395 Fedi M, Florio G. 2003. Decorrugation and removal of directional trends of magnetic 396 fields by the wavelet transform: application to archaeological areas. Geophysical 397 Prospecting 51: 261-272. DOI: 10.1046/j.1365-2478.2003.00373.x

398 Finlay CC, Maus S, Bondar TN, Chambodut A, Chernova TA, Chulliat A, Golovkov 399 VP, Hamilton B, Hamoudi M, Holme R, Hulot G, Kuang W, Langlais B, Lesur V, 400 Lowes FJ, Lühr H, Macmillan S, Mandea M, McLean S, Manoj C, Menvielle M, 401 Michaelis I, Olsen N, Rauberg J, Rother M, Sabaka TJ, Tangborn A, Tøffner-Clausen 402 L, Thébault E, Thomson AWP, Wardinski I, Wei Z, Zvereva TI. 2010. International 403 Geomagnetic Reference Field: the eleventh generation. Geophysical Journal 404 International 183: 1216-1230. DOI: 10.1111/j.1365-246X.2010.04804.X

405 Gaffney C. 2008. Detecting Trends in the Prediction of the Buried Past: A Review of 406 Geophysical Techniques in Archaeology. Archaeometry 50: 313-336. DOI: $407 \quad 10.1111 / \mathrm{j} .1475-4754.2008 .00388 . \mathrm{x}$

408 Herbich T. 2011. Geophysical surveying in Egypt: periodic report for 2009-2011. in: 409 Drahor MG, Berge MA. Archaeological Prospection. 9th International Conference on 410 Archaeological Prospection, September 19-24, 2011 Izmir (Turkey): 234-239. Istanbul. 
411 Jarvis A, Reuter HI, Nelson A, Guevara E. 2008. Hole-filled seamless SRTM data V4.

412 International Centre for Tropical Agriculture (CIAT). available from

413 http://srtm.csi.cgiar.org.

414 Leclère F. 2008. Les villes de Basse Égypte au Ier millénaire av. J.-C. Analyse 415 archéologique et historique de la topographie urbaine. Bibliothèque d'étude 144/2. 416 IFAO. Le Caire. ISBN: 978-2-7247-0491-4

417 Linford N. 2006. The application of geophysical methods to archaeological prospection. 418 Reports on Progress in Physics 69: 2205-2257. DOI: 10.1088/0034-4885/69/7/R04

419 Malecka-Drozd N. 2014. The emergence and development of architecture on the 420 casemate foundation platforms in the Nile Delta. Recherches Archéologiques Nouvelle 421 Série 4: 69-96.

422 Munschy M, Boulanger D, Ulrich P, Bouiflane M. 2007. Magnetic mapping for the 423 detection and characterization of UXO: Use of multi-sensor fluxgate 3-axis 424 magnetometers and methods of interpretation. Journal of Applied Geophysics 61: 168425 183. DOI: 10.1016/j.jappgeo.2006.06.004

426 Nabighian MN, Grauch VJS, Hansen RO, LaFehr TR, Li Y, Peirce JW, Phillips JD, 427 Ruder ME. 2005. 75th Anniversary: The historical development of the magnetic method 428 in exploration. Geophysics 70: 33-61. DOI: 10.1190/1.2133784

429 Olsen N, Tøffner-Clausen L, Sabaka TJ, Brauer P, Merayo JMG, Jörgensen JL, Léger 430 JM, Nielsen OV, Primdahl F, Risbo T. 2003. Calibration of the Ørsted vector 431 magnetometer. Earth, Planets, and Space 55: 11-18. DOI: 10.1186/BF03352458

432 Primdahl F. 1979. The fluxgate magnetometer. Journal of Physics E: Scientific 433 Instruments 12: 241-253. DOI: 10.1088/0022-3735/12/4/001

434 Spencer AJ. 1979a. Brick architecture in Ancient Egypt. Aris \& Philips; Warminster. 435 ISBN: 0856681288

436 Spencer AJ. 1979b. The brick foundations of Late Period peripteral temples and their 437 mythological origin. In: Ruffle J, Gaballa G, Kitchen K (Eds). Glimpses of Ancient 438 Egypt. Studies in Honour of H.W. Fairman: 132-137. Aris \& Philips; Warminster.

439 Svoboda JA. 2006. Prehistory of the southern Bahariya Oasis, Western Desert, Egypt. 440 An outline. Archaeology, Ethnology and Anthropology of Eurasia 28: 18-30. DOI: $441 \quad 10.1134 / \mathrm{s} 1563011006040037$

442 Svoboda JA. 2013. Prehistory of the Southern Bahariya: A case Study in Northeast 443 African Settlement Archaeology. in Dospěl, M., Suková, L. (Eds.), Bahriya Oasis. 444 Recent Research into the Past of an Egyptian Oasis: 35-62. Charles University; Prague.

445 Traunecker M. 1987. Les "temples hauts" de Basse époque : un aspect du 446 fonctionnement économique des temples, Revue d'égyptologie 38: 147-162. DOI: $447 \quad 10.2143 /$ RE.38.0.2011639 
1

2

3

4

5

6

7

8

9

10

11

12

13

14

15

16

17

18

19

20

21

22

23

24

25

26

27

28

29

30

31

32

33

34

35

36

37

38

39

40

41

42

43

44

45

46

47

48

49

50

51

52

53

54

55

56

57

58

59

60
448 Wuttman M, Bousquet B, Chauveau M, Dils P, Marchand S, Schweitzer A, Volay L. 449 1996. Premier rapport préliminaire des travaux sur le site de 'Ayn Manawir (oasis de 450 Kharga). Bulletin de l'Institut Français d'Archéologie Orientale 96: 385 - 451. 


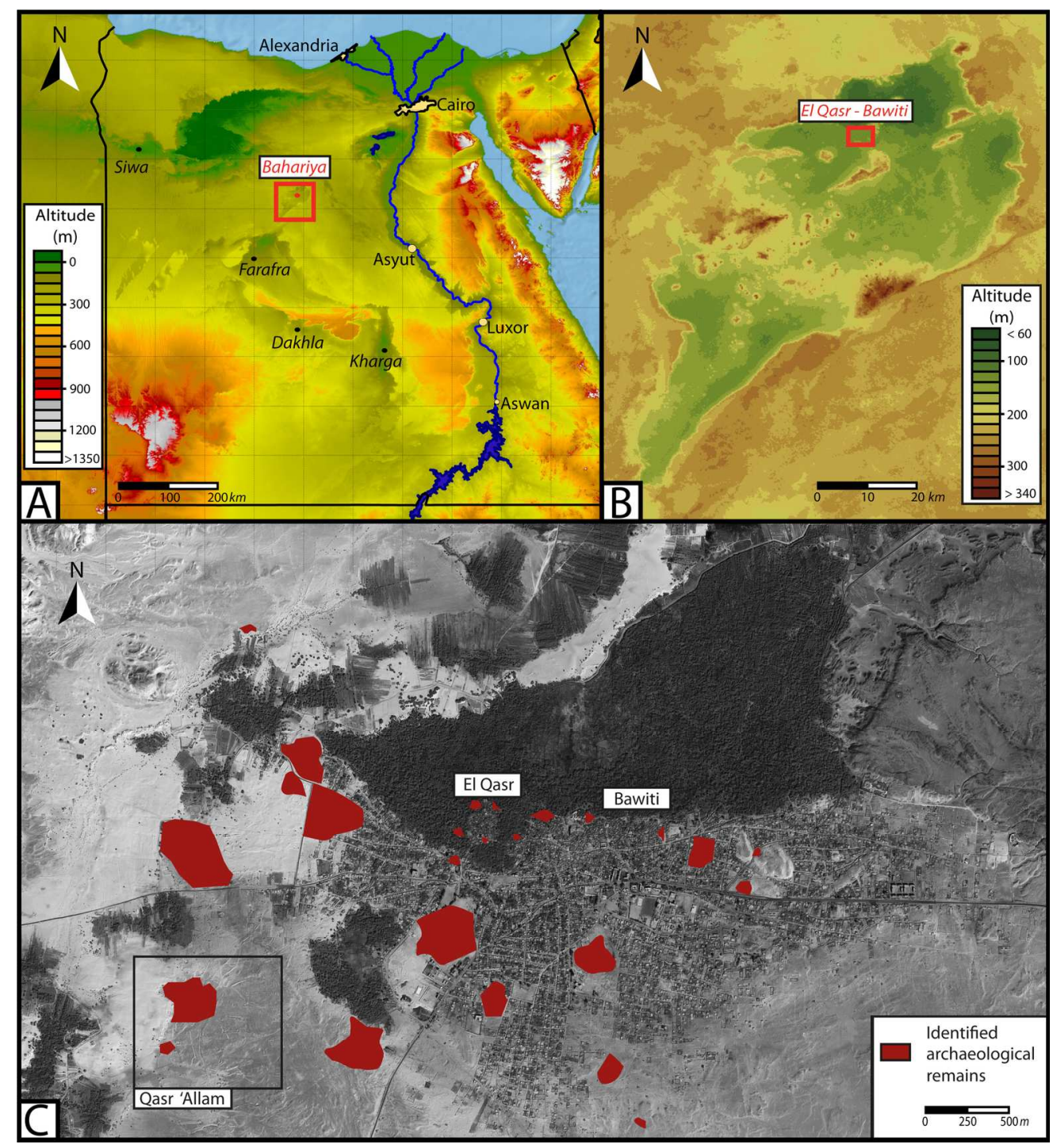

A- Localization of the oasis of Bahariya on a topographic map of Egypt. B- Localization of El Qasr-Bawiti on a topographic map of Bahariya. C- Localization of the site of Qasr 'Allam on a satellite image of El Qasr and Bawiti. Topography from SRTM90 data available at http://srtm.csi.cgiar.org/ (Jarvis et al., 2008). Satellite image from the satellites Quickbird taken in 2003 (DigitalGlobe Incorporated, Eurimage SPA licence). $164 \times 180 \mathrm{~mm}(300 \times 300 \mathrm{DPI})$ 


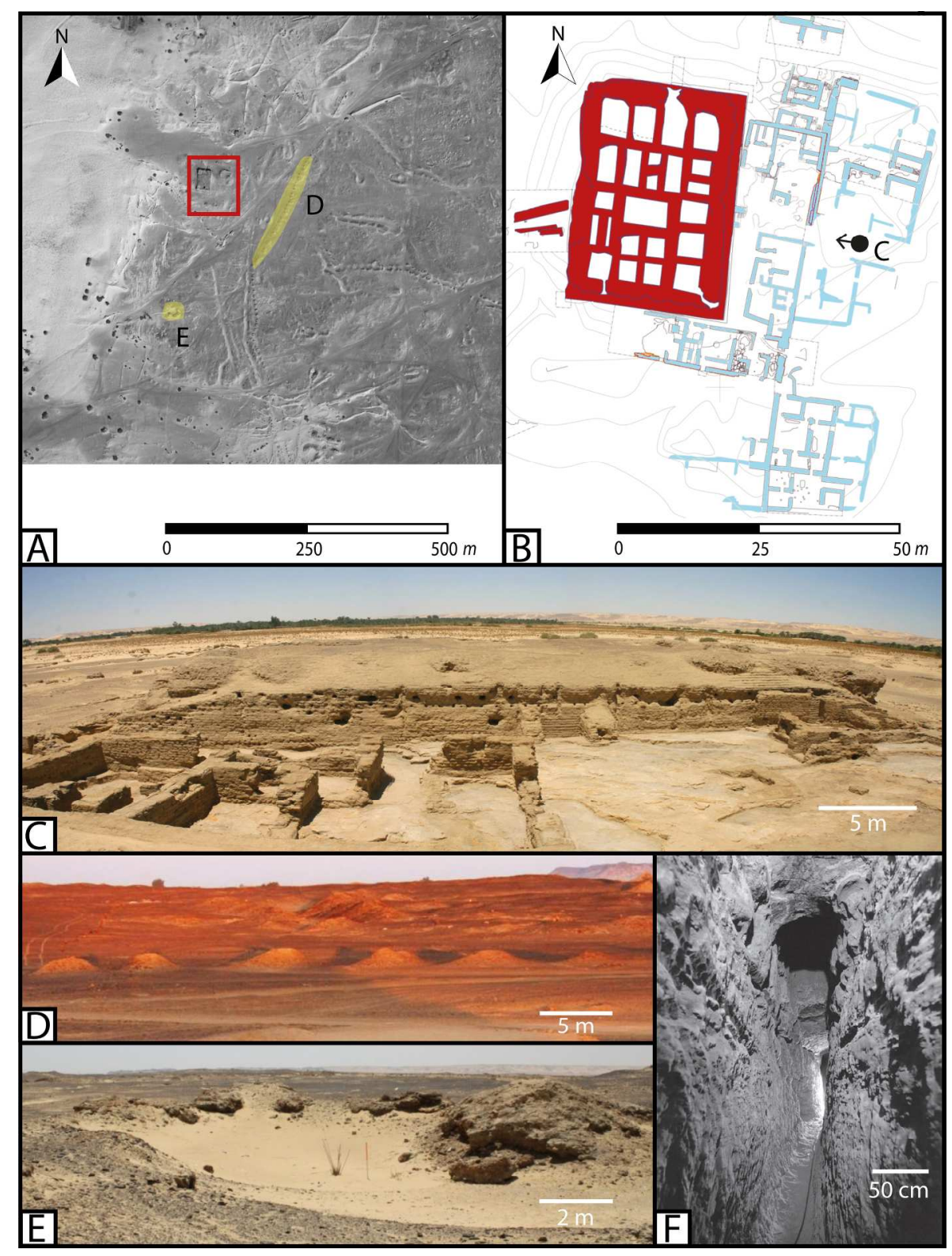

A- Localization of the excavated dwelling (red) and the irrigation structures of the pictures $D$ and $E$ (yellow) on a satellite image of Qasr 'Allam (DigitalGlobe Incorporated, Eurimage SPA licence). B- Architectural plan of the excavated dwelling and orientation of the picture $\mathrm{C}$. Blue and red colours corresponds to buildings of a first and second period of occupation. C- Lateral view of the cellular foundation platform of the second period of occupation. D- Traces of an underground channel. E- Traces of a well. F- Inside of an underground channel similar to the ones of the site and excavated in the oasis of Kharga (Wuttmann et al., 1996). $199 \times 265 \mathrm{~mm}(300 \times 300 \mathrm{DPI})$ 
A- 3-axis fluxgate magnetometer (Bartington Inc., Mag-03 MC). B- Custom electronics with 8 magnetometer inputs developed by Institut de Physique du Globe de Strasbourg (IPGS). C- Multi-sensor device developed by IPGS.

$90 \times 54 \mathrm{~mm}(300 \times 300 \mathrm{DPI})$ 
Intensity of the magnetic field measured by one magnetometer during the calibration and compensation process of the device before (blue) and after (red) corrections. Computed error parameters are given in the lower part of the figure.

$112 \times 85 \mathrm{~mm}(600 \times 600 \mathrm{DPI})$ 


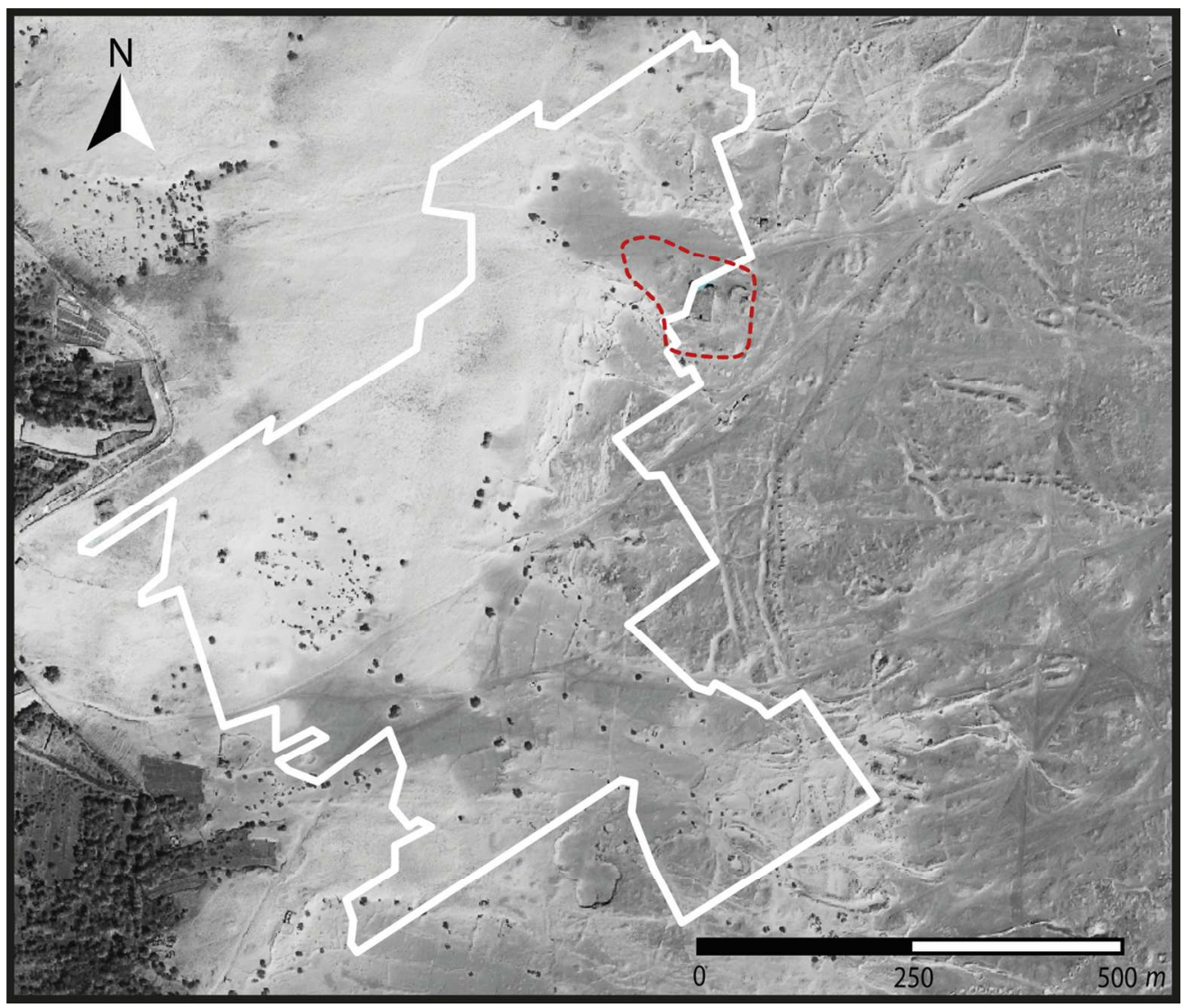

Satellite image of Qasr 'Allam (DigitalGlobe Incorporated, Eurimage SPA licence). The area of the geomagnetic prospection is delimited by the white line. The area of the excavated dwelling is delimited by the red line. $126 \times 107 \mathrm{~mm}(300 \times 300 \mathrm{DPI})$ 


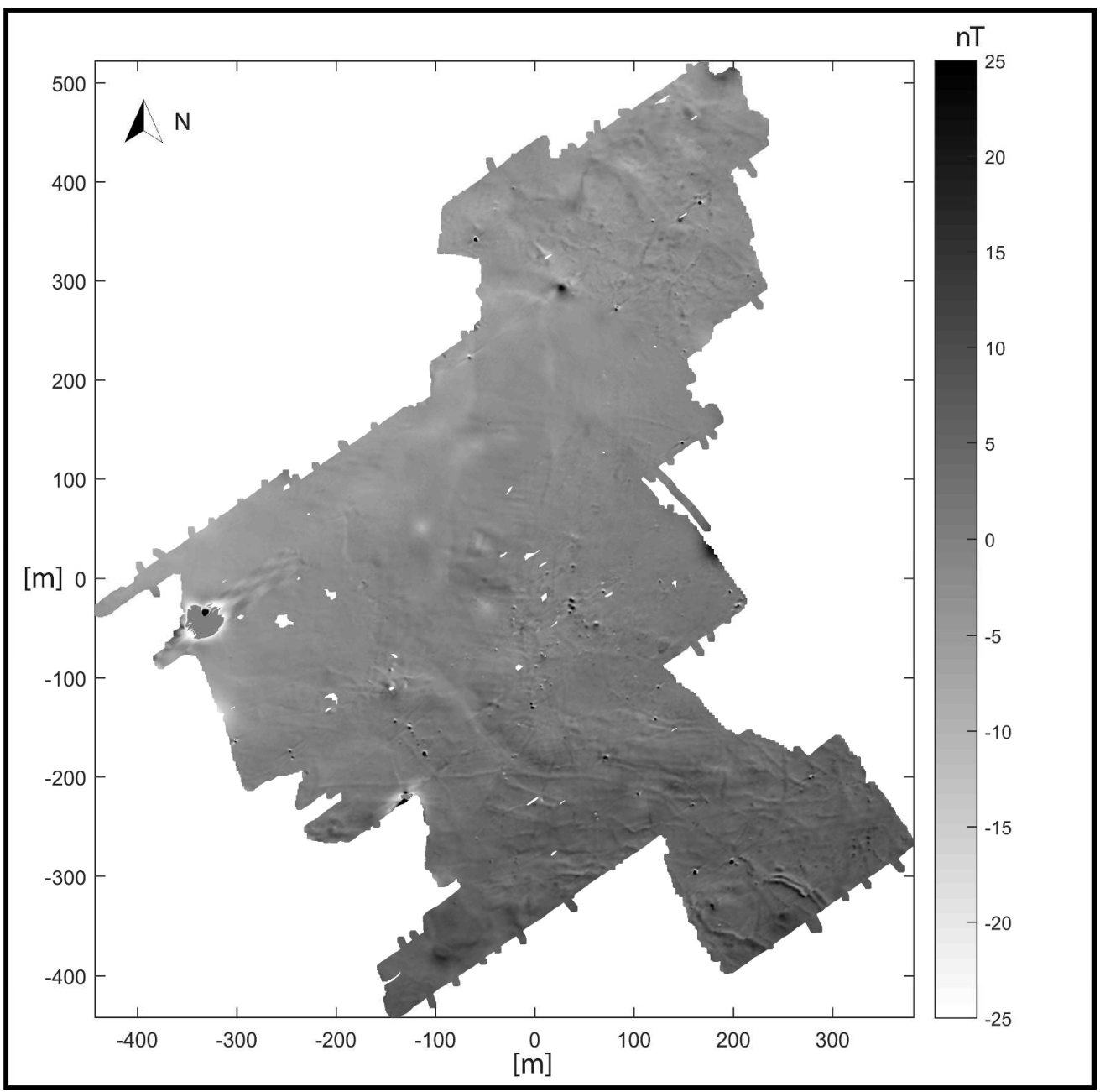

Map of the magnetic anomaly represented with a linear grayscale bar ranging from -25 to $25 \mathrm{nT}$. $148 \times 147 \mathrm{~mm}(600 \times 600 \mathrm{DPI})$ 


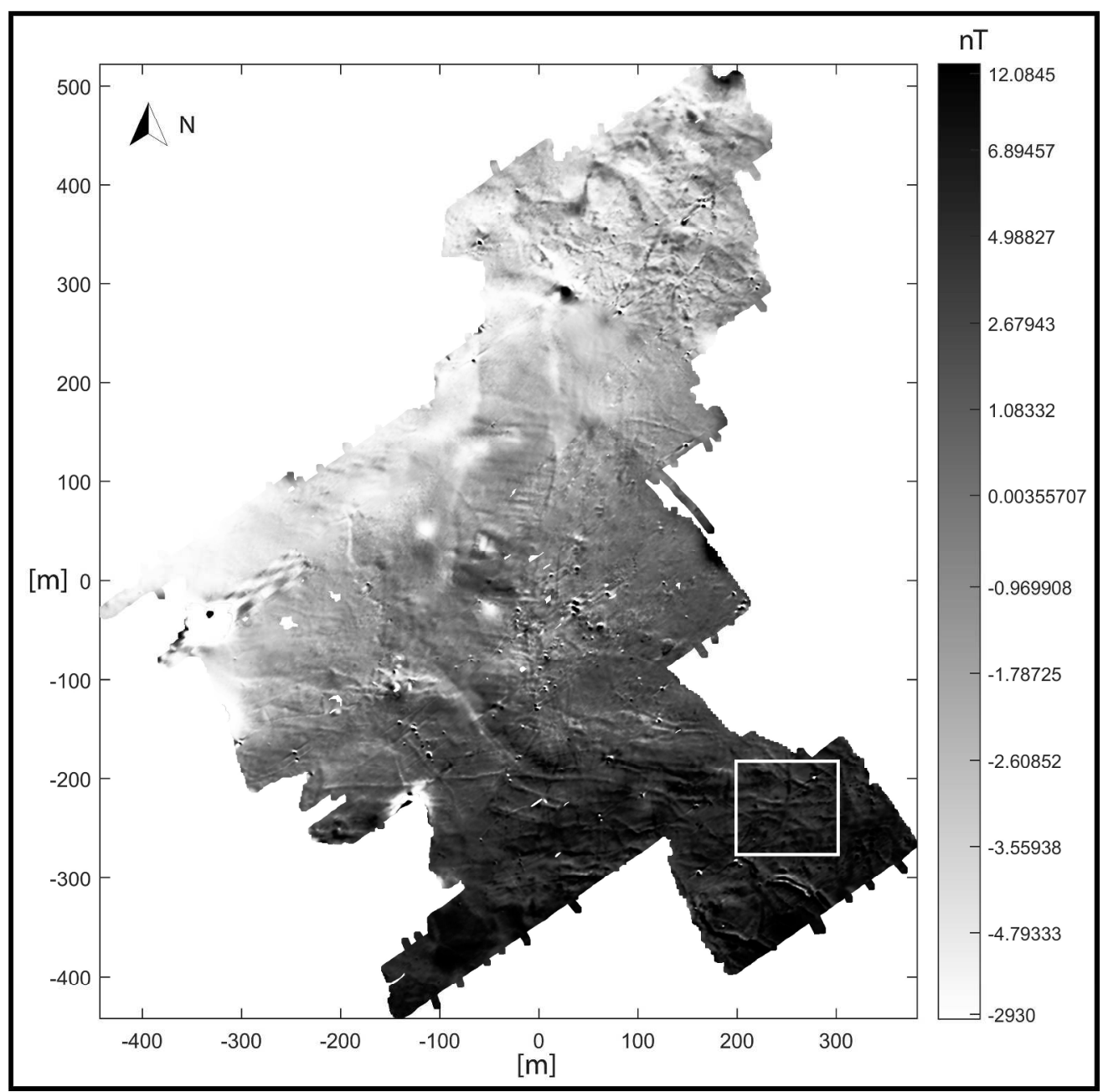

Map of magnetic anomalies represented with an equi-populated greyscale bar. The area delimited by the white line corresponds to the area displayed in Figure 8. $148 \times 147 \mathrm{~mm}(600 \times 600 \mathrm{DPI})$ 
From left to right, map of the magnetic anomaly for a sampled zone of Qasr 'Allam (Figure 7), reduction to the pole of the regional magnetic field and double reduction to the pole. The IGRF-11 was used to obtain the direction to the regional magnetic field and the magnetization direction is set equal to the IGRF direction. $59 \times 23 \mathrm{~mm}(600 \times 600 \mathrm{DPI})$ 


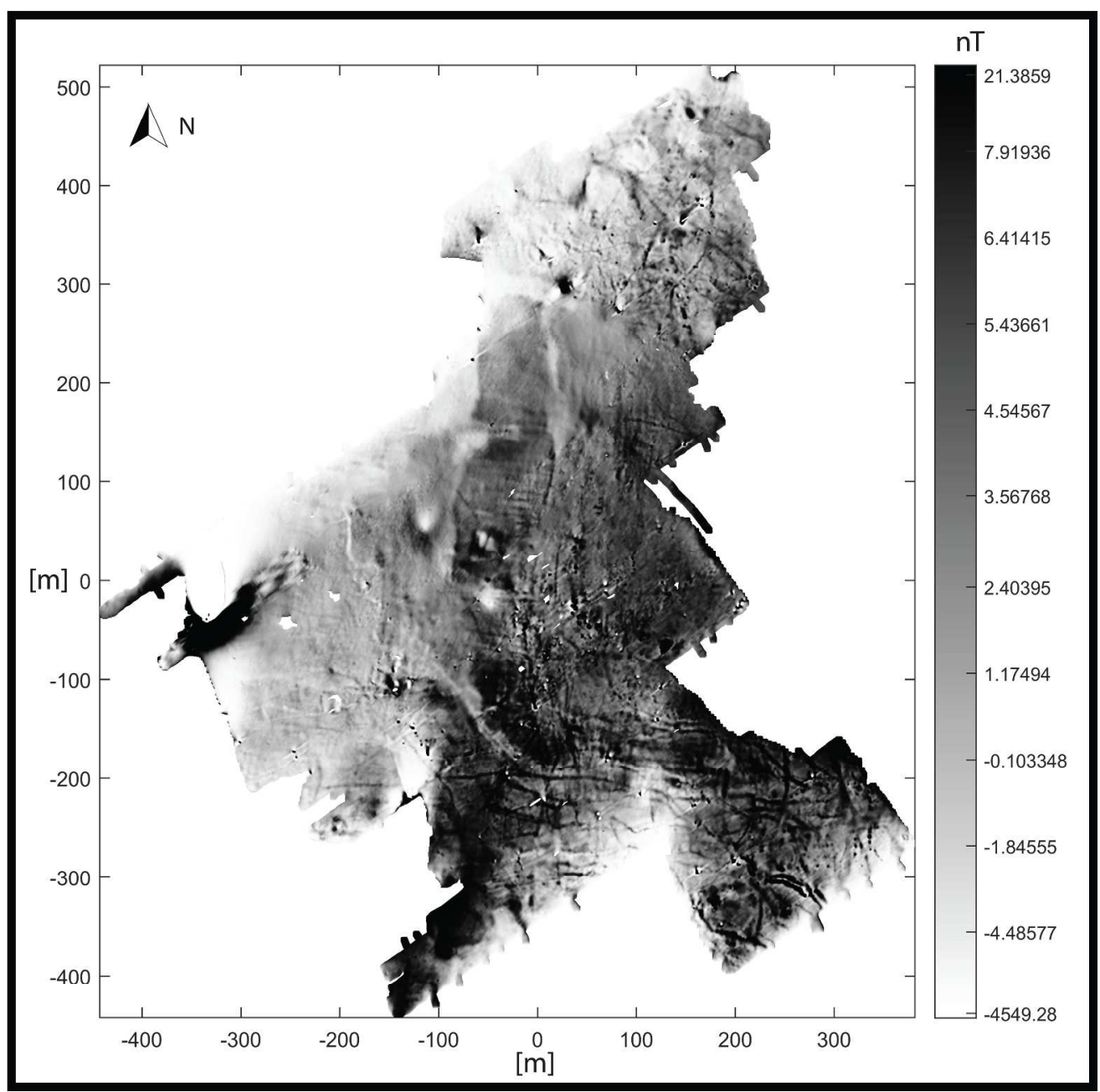

Map of the magnetic anomaly after double reduction to the pole represented with an equi-populated greyscale bar. $148 \times 147 \mathrm{~mm}(600 \times 600 \mathrm{DPI})$ 
Map of the vertical derivative of the magnetic anomaly after double reduction to the pole represented with an equi-populated greyscale bar. The enlargement corresponds to the area delimited in red. $125 \times 104 \mathrm{~mm}(600 \times 600 \mathrm{DPI})$ 


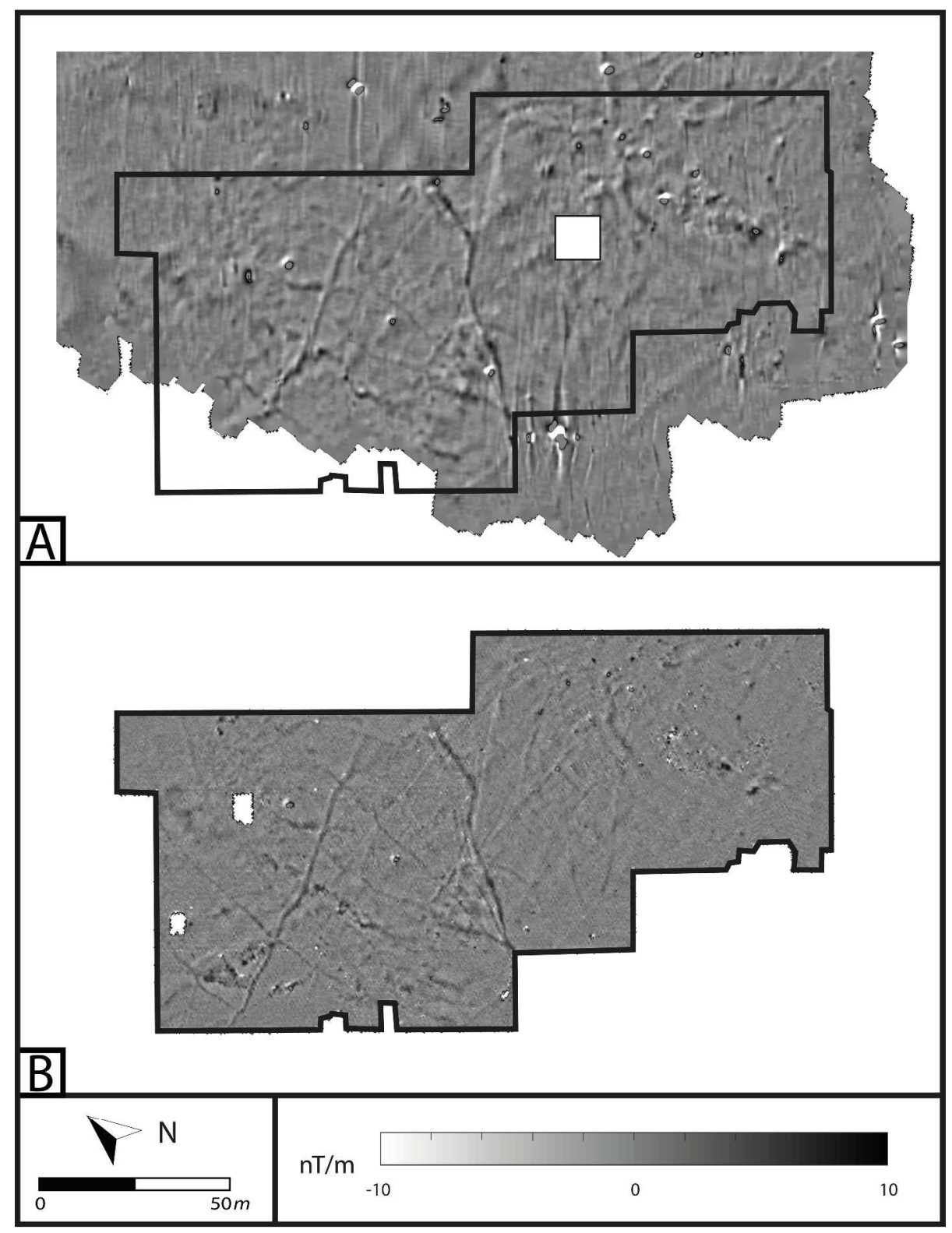

A- Map of the vertical gradient computed from the data measured with the device developed by Institut de Physique de Globe de Strasbourg (using a vertical derivative). B- Map of the vertical gradient computed from the data measured by teams directed by Tomasz Herbich with a vector gradiometer Geoscan FM256 during previous surveys (Herbich 2011). $196 \times 257 \mathrm{~mm}(600 \times 600 \mathrm{DPI})$ 
Interpretative map of the archaeological remains from the geomagnetic prospection. The hydraulic structures are represented in blue, the buildings in black. The dotted and plain red lines mark the minimal limits of the dwelling known before and after the study. The areas highlighted in green correspond to three excavations numbered 15,16 and 17. $133 \times 119 \mathrm{~mm}(300 \times 300 \mathrm{DPI})$ 